\title{
OPEN Impact of tillage and crop establishment methods on rice yields in a rice-ratoon rice cropping system in Southwest China
}

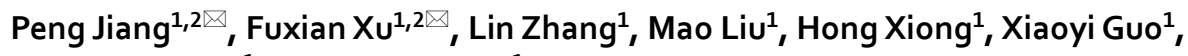 \\ Yongchuan $\mathrm{Zhu}^{1}$ \& Xingbing Zhou ${ }^{1}$
}

Simplified cultivation methods for rice production offer considerable social, economic, and environmental benefits. However, limited information is available on yield components of rice grown using simplified cultivation methods in a rice-ratoon rice cropping system. A field experiment using two hybrid and two inbred rice cultivars was conducted to compare four cultivation methods (conventional tillage and transplanting, CTTP; conventional tillage and direct seeding, CTDS; no-tillage and transplanting, NTTP; no-tillage and direct seeding, NTDS) in a rice-ratoon rice system from 2017 to 2020. Main season yields for CTDS and NTDS were higher than for CTTP by $6.1 \%$ and 2.8\%, respectively; whereas ratoon season yields for CTDS and NTDS were equal to or higher than for CTTP. Annual grain yields for CTDS and NTDS were higher than for CTTP by $4.4 \%$ and $3.2 \%$, respectively. The higher CTDS and NTDS yields were associated with higher panicle numbers per $\mathrm{m}^{2}$ and biomass production. Rice hybrids had higher yields than inbred cultivars by $15.8-19.3 \%$ for main season and by $15.6-19.4 \%$ for ratoon season, which was attributed to long growth duration, high grain weight and biomass production. Our results suggest that CTTP can be replaced by CTDS and NTDS to maintain high grain yields and save labor costs. Developing cultivars with high grain weight could be a feasible approach to achieve high rice yields in the rice-ratoon rice cropping system in southwest China.

Rice is the main staple food crop that supports a large segment of the global population ${ }^{1}$. It has been estimated that global rice production must increase by 116 million tons by 2035 to meet the growing demand for food that will result from predicted population growth ${ }^{2}$. In addition, China will need to produce approximately $20 \%$ more rice by 2030 to meet its projected domestic needs ${ }^{3}$. Further increases in rice production in China are mainly dependent on more frequent harvests on the existing cropland ${ }^{4,5}$. In recent years, the area of arable cropland used for rice production has been decreasing because of increasing use of land for urbanization ${ }^{6}$. Yield gap analysis has also shown that rice yields have been approaching their potential biophysical ceiling ${ }^{7,8}$, and the average annual growth rate was $-0.3 \%$ from 1998 to 2006 in China ${ }^{9}$. In general, multiple rice cropping systems include double-season rice, triple-season rice, and ratoon rice; the double-season rice system is the dominant multiple rice cropping system used in China and elsewhere in Asia ${ }^{10}$. However, the planting area of the double rice cropping systems in China has continued to decline because of labor shortages, a low level of mechanization, and low production efficiency ${ }^{11}$. To ensure rice self-sufficiency and food security, strategies to increase the productivity of multiple rice cropping systems are desperately needed.

Ratoon rice (Fig. 1), which is the practice of obtaining a second harvest from tillers originating from the stubble remaining after harvesting the main rice crop, has emerged as an alternative option to replace double-season rice $^{12}$. This is called a "one planting and two harvests" cropping system. Ratoon rice crops are characterized by short growth periods, high daily yields, high rice quality, low labor requirements, low water usage, reduced seed usage, reduced production costs, and increased yield and profits ${ }^{13}$. With progress in rice breeding and improvement crop management practices, and shortage of labor, use of rice ratooning has rapidly expanded in China ${ }^{14,15}$,

\footnotetext{
${ }^{1}$ Rice and Sorghum Research Institute, Sichuan Academy of Agricultural Sciences/Key Laboratory of Southwest Rice Biology and Genetic Breeding, Ministry of Agriculture, Deyang 618000, China. ${ }^{2}$ Crop Ecophysiology and Cultivation Key Laboratory of Sichuan Province, Wenjiang 611130, China. ${ }^{\circledR}$ email: jiangyipeng137@163.com; xu6501@163.com
} 


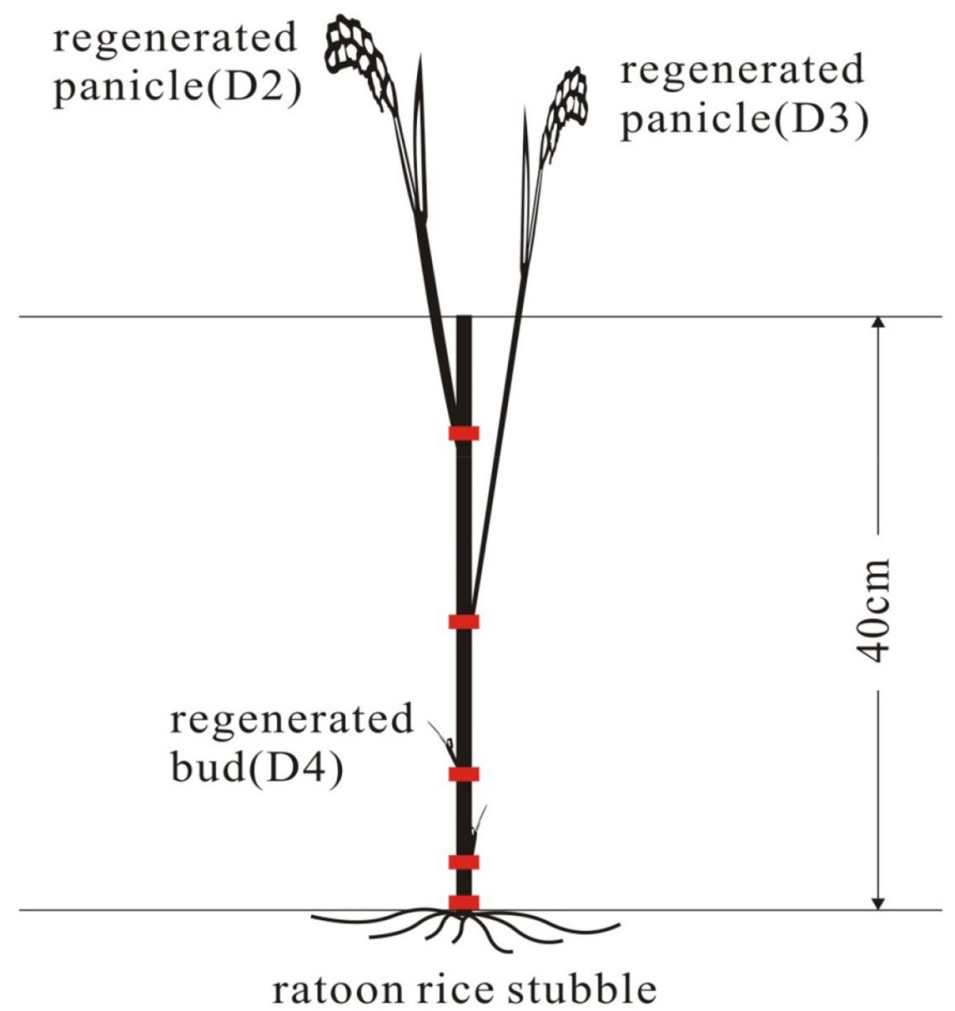

Figure 1. The brief diagram of the nodes, regenerated panicles and regenerated buds in ratoon rice system. D2, D3 and D4 represent the second node from top, third node from the top, and other nodes below the third node from main crop tillers.

the total planted area of ratoon rice cultivation was more than 1.24 million hectares in $2020^{16}$. The practice of ratoon rice has also rapidly increasing in USA and Africa and elsewhere in world ${ }^{17-19}$. The grain yield of ratoon rice is more than $6.0 \mathrm{tha}^{-1}$ if the crop is properly managed ${ }^{20}$.

At present, conventional tillage is the most widely used method for land preparation of paddy fields for the main season rice crop. In ratoon rice systems, the crop establishment method used for the main season crop is mainly seedling transplantation, which is still the dominant method used in China. Transplanting seedlings requires a large amount of manpower and the task is very labor-intensive and involves working in a stooping posture and moving in a muddy field ${ }^{21}$. Paradoxically, labor availability is limited in China because an increasing number of young farmers have left for jobs in the cities, leaving the older farmers behind. Recently, simplified cultivation technologies for rice production have become increasingly attractive because the potential benefits include savings on labor, reduced water use, lower greenhouse gas emissions, and reduced environmental risks as well as improved rice yield if the crop is properly managed 22 .

Simplified cultivation technologies for rice production commonly rely on simplifying the methods used for crop establishment, or land preparation, or both. At present, several simplified cultivation technologies, such as conventional tillage and direct seeding (CTDS), no-tillage and direct seeding (NTDS), conventional tillage and seedling broadcasting (CTSB), no-tillage and seedling broadcasting (NTSB), and no-tillage and transplanting (NTTP), have been developed in China for rice production. The adoption of simplified cultivation technologies for producing the main rice crop in place of conventional transplanting is continuously increasing in Asia, because this can potentially reduce production costs through savings on fuel and labor while maintaining grain yields and increasing system productivity and resource use efficiency compared with conventional transplanting ${ }^{23,24}$. However, the effects of simplified cultivation technologies on rice yields in the rice-ratoon rice cropping system is still unknown.

Rice yield is determined by the number of panicles per unit land area, the spikelet number per panicle, the spikelet filling percentage, and grain weight. Lin et al. showed that the number of spikelets per panicle contributed the most to grain yield in the main rice crop, and the number of panicles per unit area of land contributed the most to grain yield in ratoon rice through the sink size (spikelet number per unit land area) ${ }^{25}$. The grain yield of ratoon rice is significantly and positively correlated with the number of panicles per unit land area ${ }^{26}$. The largest planting area of ratoon rice in China is in southwest China, and accounts for $40 \%$ of the current total land area devoted to ratoon rice. However, rice farmers transplant rice seedlings at extremely wide spacing in southwest China due to the shortage of rural labor and increased labor costs ${ }^{3}$. Grain yields of the main rice crop and ratoon rice in the farmers' paddy fields planted at low density were only $93 \%$ and $70 \%$, respectively, of the yield from 666 hectares of demonstration fields planted at high density; and the average total yield in the farmers' paddy fields 


\begin{tabular}{|c|c|c|c|c|c|c|c|}
\hline Cultivar & Year & SW-HD ${ }^{\mathrm{a}}(\mathrm{d})$ & HD-MH (d) & $\begin{array}{l}\text { Main crop duration } \\
\text { (d) }\end{array}$ & MH-HDR (d) & HDR-RH (d) & $\begin{array}{l}\text { Ratoon crop } \\
\text { duration (d) }\end{array}$ \\
\hline \multirow{4}{*}{ HHZ \& JNSM } & 2017 & 112 & 30 & 142 & 34 & 30 & 64 \\
\hline & 2018 & 110 & 30 & 140 & 32 & 32 & 64 \\
\hline & 2019 & 111 & 30 & 141 & 34 & 30 & 64 \\
\hline & 2020 & 111 & 30 & 141 & 34 & 31 & 65 \\
\hline \multirow{4}{*}{ NY103 \& RY1015 } & 2017 & 119 & 32 & 151 & 38 & 32 & 70 \\
\hline & 2018 & 117 & 32 & 149 & 38 & 33 & 71 \\
\hline & 2019 & 118 & 33 & 151 & 37 & 31 & 68 \\
\hline & 2020 & 117 & 33 & 150 & 39 & 33 & 72 \\
\hline
\end{tabular}

Table1. Growth duration of four rice cultivars in main rice crop -ratoon rice system in 2017-2020. ${ }^{\text {S }}$ WW-HD, from sowing to heading; $\mathrm{HD}-\mathrm{MH}$, from heading to harvest of the main rice crop; $\mathrm{MH}-\mathrm{HDR}$, from harvest of the main rice crop to heading of the ratoon rice; HDR-RH, from heading of the ratoon rice to harvest of the ratoon rice. ${ }^{\mathrm{b}} \mathrm{HHZ}$, JNSM, NY103 and RY015 are Huanghuazhan, Jinnongsimiao, Nei6you103 and Rongyou1015, respectively.

was approximately $1.5 \mathrm{tha}^{-1}$ lower than that in the demonstration fields ${ }^{13}$. These results indicate that the number of panicles per unit land area plays a vital role in yield formation in ratoon rice, which depends on the ability of the meristematic buds to regenerate, or the number of mother stems per unit land area, or both. The ability of the buds to regenerate is affected by both genetics and management practice factors. Xu et al. has suggested that the selection of genotypes with strong bud regeneration ability in breeding programs could be an effective way to achieve an increase in panicle number per unit land area in the ratoon season $\mathrm{crop}^{13}$. Huang et al. reported that grain yield in the direct-seeded (DS) main rice crop was higher than in the main crop using conventional transplanting (CT), and that this was mainly due to the higher panicle number per $\mathrm{m}^{2}$ of the main rice $\mathrm{crop}^{27}$. These results imply that the panicle number per $\mathrm{m}^{2}$ in the ratoon season can be increased by increasing the number of rice mother stems through the use of DS. However, limited information is available on grain yield and yield components in rice grown using simplified cultivation technologies in the rice-ratoon rice cropping system. A four-year field experiment was conducted with the following aims: (1) to examine the effects of simplified cultivation technologies on grain yield in the rice-ratoon rice cropping system; (2) to the determine yield formation characteristics of rice grown using simplified cultivation technologies in the rice-ratoon rice cropping system.

\section{Results}

Crop growth and development. The length of the ratoon growth season was $45-48 \%$ that of main season (Table 1). The lengths of the main and ratoon growing seasons were similar for the four years of the experiment. Hybrid rice cultivars with longer main growing seasons also had longer ratoon growing seasons. The total main season growth durations for the rice hybrids were 9-10 days longer than for the inbred rice cultivars. The longer total main season growth duration of the rice hybrids was mainly attributed to the longer growing time from sowing to heading. Similarly, the total growth duration for the ratoon season was longer for the rice hybrids than for the inbred rice cultivars by $4-7$ days.

Climatic condition. The maximum and minimum temperatures were slightly higher for the rice hybrids from sowing (SW) to heading (HD) and from HD to harvest for the main rice crop (MH) than for the rice inbreds during the main growing season (Table 2). However, the rice hybrids experienced lower maximum and minimum temperatures from $\mathrm{MH}$ to heading of the ratoon rice (HDR) and from HDR to harvest of the ratoon rice $(\mathrm{RH})$ than did the rice inbred lines in the ratoon growing season. The solar radiation was $1.7 \%$ lower for the rice hybrids from SW to HD than for the rice inbreds during the main growing season, while there was 3.9\% higher solar radiation for the rice hybrids from HD to MH than for the rice inbreds. Rice hybrids had lower solar radiation than did rice inbreds by $10.6 \%$ from $\mathrm{MH}$ to HDR and by $13.6 \%$ from HDR to RH during the ratoon rice growing season.

Grain yield and its attributes. Main season yield significantly differed among cultivation method treatments $(\mathrm{T})$ and rice cultivars $(\mathrm{C})$, whereas the interactive effects of $\mathrm{T} \times \mathrm{C}$ were not significant for main season yield (except 2019) (Table 3). The effects of T, C and their interaction were significantly on ratoon season yield in 2018 but were not significant in 2017. Ratoon season yield was significantly affected by C in 2019 and 2020, but not by $\mathrm{T}$ and the interaction of $\mathrm{T} \times \mathrm{C}$. Annual yield significantly differed among $\mathrm{T}$ and $\mathrm{C}$. The interactive effect of $\mathrm{T} \times \mathrm{C}$ was significant for annual yield in 2018 and 2019 but was not significant in 2017 and 2020 .

Mean main season yield across four rice cultivars and four years under CTDS and NTDS treatments reached to 9.34 and $9.05 \mathrm{t} \mathrm{ha}^{-1}$, respectively, which were approximately $6.1 \%$ and $2.8 \%$ higher than the yields under CTTP treatment, respectively (Table 3). However, grain yield of ratoon rice for the CTDS and NTDS treatments was equal to or higher than for the CTTP treatment. Consequently, the annual grain yield for rice grown using CTDS and NTDS treatments was $4.4 \%$ and 3.2\% higher, respectively, than for rice grown using CTTP treatment. Main season yield, ratoon season yield, and annual grain yield for the NTTP treatment were equal to or higher than for the CTTP treatment. 


\begin{tabular}{|c|c|c|c|c|c|}
\hline Cultivar & Year & SW-HD ${ }^{\mathrm{a}}$ & HD-MH & MH-HDR & HDR-RH \\
\hline \multicolumn{6}{|c|}{ Maximum temperature $\left({ }^{\circ} \mathrm{C}\right)$} \\
\hline \multirow{5}{*}{ HHZ \& JNSM ${ }^{b}$} & 2017 & 25.9 & 35.2 & 33.0 & 26.7 \\
\hline & 2018 & 27.5 & 34.1 & 34.6 & 24.3 \\
\hline & 2019 & 26.0 & 31.1 & 33.3 & 27.1 \\
\hline & 2020 & 26.9 & 30.7 & 33.8 & 24.6 \\
\hline & Mean & 26.6 & 32.8 & 33.7 & 25.7 \\
\hline \multirow{5}{*}{ NY103 \& RY1015 } & 2017 & 26.3 & 35.6 & 31.6 & 22.9 \\
\hline & 2018 & 27.6 & 35.1 & 31.2 & 21.5 \\
\hline & 2019 & 26.1 & 32.1 & 31.8 & 24.9 \\
\hline & 2020 & 27.0 & 32.4 & 30.8 & 20.8 \\
\hline & Mean & 26.7 & 33.8 & 31.3 & 22.5 \\
\hline \multicolumn{6}{|c|}{ Minimum temperature $\left({ }^{\circ} \mathrm{C}\right)$} \\
\hline \multirow{5}{*}{ HHZ \& JNSM } & 2017 & 18.0 & 26.2 & 24.6 & 21.0 \\
\hline & 2018 & 19.0 & 25.6 & 25.3 & 20.1 \\
\hline & 2019 & 18.4 & 23.9 & 24.4 & 20.2 \\
\hline & 2020 & 18.5 & 24.1 & 24.7 & 19.8 \\
\hline & Mean & 18.5 & 24.9 & 24.7 & 20.2 \\
\hline \multirow{5}{*}{ NY103 \& RY1015 } & 2017 & 18.4 & 26.2 & 23.8 & 18.4 \\
\hline & 2018 & 19.4 & 25.5 & 23.8 & 17.3 \\
\hline & 2019 & 18.6 & 24.7 & 23.5 & 18.3 \\
\hline & 2020 & 18.8 & 25.0 & 22.8 & 17.1 \\
\hline & Mean & 18.8 & 25.3 & 23.5 & 17.8 \\
\hline \multicolumn{6}{|c|}{ Solar radiation $\left(\mathrm{MJ} \mathrm{m}^{-2} \mathrm{~d}^{-1}\right)$} \\
\hline \multirow{5}{*}{ HHZ \& JNSM } & 2017 & 17.1 & 19.4 & 17.3 & 12.2 \\
\hline & 2018 & 18.1 & 18.8 & 18.5 & 10.6 \\
\hline & 2019 & 16.2 & 17.2 & 17.8 & 13.4 \\
\hline & 2020 & 17.4 & 16.2 & 18.1 & 11.1 \\
\hline & Mean & 17.2 & 17.9 & 17.9 & 11.8 \\
\hline \multirow{5}{*}{ NY103 \& RY1015 } & 2017 & 17.0 & 19.7 & 15.9 & 10.0 \\
\hline & 2018 & 16.2 & 18.8 & 15.6 & 9.5 \\
\hline & 2019 & 15.7 & 17.4 & 16.4 & 12.2 \\
\hline & 2020 & 16.9 & 17.2 & 16.1 & 8.9 \\
\hline & Mean & 16.5 & 18.3 & 16.0 & 10.2 \\
\hline
\end{tabular}

Table 2. Maximum temperature, minimum temperature and solar radiation during the rice-growing season

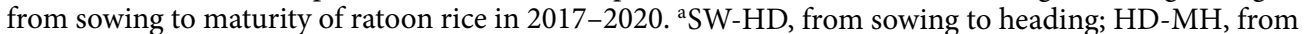
heading to harvest of the main rice crop; MH-HDR, from harvest of the main rice crop to heading of the ratoon rice; HDR-RH, from heading of the ratoon rice to harvest of the ratoon rice. ${ }^{b} \mathrm{HHZ}$, JNSM, NY103 and RY015 are Huanghuazhan, Jinnongsimiao, Nei6you 103 and Rongyou1015, respectively.

A large difference was observed in main season yield and ratoon season yield between the rice hybrids and the inbred cultivars (Table 3), though the magnitude of the difference in main season yield and ratoon season yield between the rice hybrids and the inbred cultivars varied by cultivation method. Average across four years, the rice hybrids had higher main season yields than did the rice inbreds by $16.2 \%$ under CTDS, by $15.8 \%$ under NTDS, by $19.3 \%$ under NTTP and by $17.6 \%$ under CTTP. The main season yield gap between the hybrid and inbred rice were larger in transplanting treatment. The ratoon season yields for rice hybrids were higher than for rice inbreds by $19.4 \%$ under CTDS, by $16.7 \%$ under NTDS, by $15.6 \%$ under NTTP and by $15.7 \%$ under CTTP. The ratoon season yield gap between the hybrid and inbred rice were larger in direct seeding treatment. The difference in annual yield among four rice cultivars were significant in all four experiments. On average, the hybrids had $17.1 \%$ higher annual grain yield than did the inbred cultivars.

The main season yields were $21.8 \%, 28.1 \%$, and $27.7 \%$ higher in 2017 than in 2018, 2019, and 2020, respectively. The ratoon season yield was similar to, or slightly higher in 2017, than it was in 2018, 2019, and 2020. As a result, the annual grain yields were $20.8 \%, 20.5 \%$, and $17.7 \%$ higher than in 2018,2019 , and 2020, respectively.

The yield components of main rice crop were significantly affected by year (Y), cultivation method treatment (T) and cultivar (C), except the effect of $\mathrm{T}$ for grain weight (Table 4). The interactive effects of $\mathrm{Y} \times \mathrm{T}, \mathrm{T} \times \mathrm{C}$ and $\mathrm{Y} \times \mathrm{T} \times \mathrm{C}$ were significant for panicles per $\mathrm{m}^{2}$ and spikelets per panicle in the main season rice crop but were not significant for grain filling and grain weight in the main rice crop. There was a significant $\mathrm{Y} \times \mathrm{C}$ interactive effect on panicles per $\mathrm{m}^{2}$, spikelets per panicle, spikelets per $\mathrm{m}^{2}$, grain filling, and grain weight in the main rice crop.

The panicles per $\mathrm{m}^{2}$ in the main rice crop for the CTDS and NTDS treatments were $45.8 \%$ and $35.0 \%$ higher than for the CTTP treatment, respectively, and there were $21.5 \%$ and $15.8 \%$ fewer spikelets per panicle in the 


\begin{tabular}{|c|c|c|c|c|c|c|c|c|c|c|c|c|c|}
\hline \multirow[b]{2}{*}{ Treatment } & \multirow[b]{2}{*}{ cultivar } & \multicolumn{3}{|l|}{2017} & \multicolumn{3}{|l|}{2018} & \multicolumn{3}{|l|}{2019} & \multicolumn{3}{|l|}{2020} \\
\hline & & Main yield & \begin{tabular}{|l|} 
Ratoon \\
yield
\end{tabular} & $\begin{array}{l}\text { Annual } \\
\text { yield }\end{array}$ & $\begin{array}{l}\text { Main } \\
\text { Yield }\end{array}$ & \begin{tabular}{|l|}
$\begin{array}{l}\text { Ratoon } \\
\text { yield }\end{array}$ \\
\end{tabular} & $\begin{array}{l}\text { Annual } \\
\text { yield }\end{array}$ & Main yield & $\begin{array}{l}\text { Ratoon } \\
\text { yield }\end{array}$ & $\begin{array}{l}\begin{array}{l}\text { Annual } \\
\text { yield }\end{array} \\
\end{array}$ & Main yield & $\begin{array}{l}\begin{array}{l}\text { Ratoon } \\
\text { yield }\end{array} \\
\end{array}$ & \begin{tabular}{|l|}
$\begin{array}{l}\text { Annual } \\
\text { yield }\end{array}$ \\
\end{tabular} \\
\hline \multirow{5}{*}{ CTDS } & HHZ & $10.17 \mathrm{c}$ & $3.15 \mathrm{bc}$ & $13.32 \mathrm{c}$ & $8.89 \mathrm{c}$ & $2.28 \mathrm{~b}$ & $11.17 \mathrm{c}$ & $8.24 \mathrm{~b}$ & $2.87 \mathrm{c}$ & $11.11 \mathrm{~b}$ & $7.91 \mathrm{~b}$ & $3.27 \mathrm{c}$ & $11.18 \mathrm{~b}$ \\
\hline & JNSM & $9.80 \mathrm{c}$ & $2.91 \mathrm{c}$ & $12.71 \mathrm{c}$ & $8.34 \mathrm{c}$ & $2.57 \mathrm{~b}$ & $10.90 \mathrm{c}$ & $7.87 \mathrm{~b}$ & $3.34 \mathrm{~b}$ & $11.21 \mathrm{~b}$ & $7.86 \mathrm{~b}$ & $3.09 \mathrm{c}$ & $10.94 \mathrm{~b}$ \\
\hline & NY103 & $12.12 \mathrm{a}$ & $3.63 \mathrm{a}$ & $15.75 \mathrm{a}$ & $9.54 \mathrm{~b}$ & $2.84 \mathrm{~b}$ & $12.39 \mathrm{~b}$ & $9.46 \mathrm{a}$ & $3.63 \mathrm{a}$ & $13.09 \mathrm{a}$ & $8.98 \mathrm{a}$ & $4.07 \mathrm{a}$ & $13.05 \mathrm{a}$ \\
\hline & RY1015 & $11.28 \mathrm{~b}$ & $3.49 \mathrm{ab}$ & $14.77 \mathrm{~b}$ & $10.14 \mathrm{a}$ & $3.53 \mathrm{a}$ & $13.67 \mathrm{a}$ & $9.42 \mathrm{a}$ & $3.24 \mathrm{~b}$ & $12.66 \mathrm{a}$ & $9.35 \mathrm{a}$ & $3.60 \mathrm{~b}$ & $12.95 \mathrm{a}$ \\
\hline & Mean & $10.84 \mathrm{~A}$ & $3.29 \mathrm{AB}$ & $14.13 \mathrm{AB}$ & $9.23 \mathrm{~A}$ & $2.80 \mathrm{AB}$ & $12.03 \mathrm{~A}$ & $8.75 \mathrm{~A}$ & $3.27 \mathrm{~A}$ & $12.02 \mathrm{~A}$ & $8.52 \mathrm{~A}$ & $3.51 \mathrm{~A}$ & $12.03 \mathrm{~A}$ \\
\hline \multirow{5}{*}{ NTDS } & $\mathrm{HHZ}$ & $10.26 \mathrm{~b}$ & $3.60 \mathrm{a}$ & $13.86 \mathrm{ab}$ & $8.64 \mathrm{ab}$ & $2.14 \mathrm{c}$ & $10.79 \mathrm{~b}$ & $7.53 \mathrm{c}$ & $2.84 \mathrm{c}$ & $10.36 \mathrm{~b}$ & $7.37 \mathrm{~b}$ & $3.33 c$ & $10.7 \mathrm{~b}$ \\
\hline & JNSM & $9.57 \mathrm{~b}$ & $3.49 \mathrm{a}$ & $13.06 \mathrm{~b}$ & $8.13 \mathrm{~b}$ & $2.78 \mathrm{~b}$ & $10.91 \mathrm{~b}$ & $7.70 \mathrm{bc}$ & $3.42 \mathrm{a}$ & $11.12 \mathrm{ab}$ & $7.90 \mathrm{~b}$ & $3.23 \mathrm{c}$ & $11.13 \mathrm{~b}$ \\
\hline & NY103 & $11.68 \mathrm{a}$ & $3.44 \mathrm{a}$ & $15.12 \mathrm{a}$ & $9.36 \mathrm{ab}$ & $4.43 \mathrm{a}$ & $13.79 \mathrm{a}$ & $8.64 \mathrm{ab}$ & $3.36 \mathrm{ab}$ & $12.00 \mathrm{a}$ & $8.84 \mathrm{a}$ & $4.26 \mathrm{a}$ & $13.10 \mathrm{a}$ \\
\hline & RY1015 & $11.41 \mathrm{a}$ & $3.49 \mathrm{a}$ & $14.89 \mathrm{a}$ & $9.71 \mathrm{a}$ & $3.03 \mathrm{~b}$ & $12.75 \mathrm{a}$ & $8.89 \mathrm{a}$ & $3.27 \mathrm{~b}$ & $12.16 \mathrm{a}$ & $9.20 \mathrm{a}$ & $3.69 \mathrm{~b}$ & $12.88 \mathrm{a}$ \\
\hline & Mean & $10.73 \mathrm{AB}$ & $3.50 \mathrm{~A}$ & $14.23 \mathrm{~A}$ & $8.96 \mathrm{~A}$ & $3.10 \mathrm{~A}$ & $12.06 \mathrm{~A}$ & $8.19 \mathrm{~B}$ & $3.22 \mathrm{~A}$ & $11.41 \mathrm{~B}$ & $8.32 \mathrm{~A}$ & $3.63 \mathrm{~A}$ & $11.95 \mathrm{~A}$ \\
\hline \multirow{5}{*}{ NTTP } & HHZ & $9.61 \mathrm{~b}$ & $3.19 \mathrm{a}$ & $12.79 \mathrm{c}$ & $7.9 \mathrm{~b}$ & $2.14 \mathrm{~b}$ & $10.04 \mathrm{~b}$ & $7.19 \mathrm{~b}$ & $3.05 \mathrm{c}$ & $10.24 \mathrm{~b}$ & $7.68 \mathrm{~b}$ & $3.21 \mathrm{~b}$ & $10.89 \mathrm{~b}$ \\
\hline & JNSM & $9.45 \mathrm{~b}$ & $3.07 \mathrm{a}$ & $12.53 \mathrm{c}$ & $7.34 \mathrm{~b}$ & $2.43 \mathrm{~b}$ & $9.77 \mathrm{~b}$ & $7.08 \mathrm{~b}$ & $3.30 \mathrm{bc}$ & $10.39 \mathrm{~b}$ & $6.89 c$ & $3.36 \mathrm{~b}$ & $10.25 \mathrm{c}$ \\
\hline & NY103 & $11.63 \mathrm{a}$ & $3.41 \mathrm{a}$ & $15.04 \mathrm{a}$ & $8.62 \mathrm{a}$ & $3.3 \mathrm{a}$ & $11.91 \mathrm{a}$ & $9.11 \mathrm{a}$ & $3.82 \mathrm{a}$ & $12.93 \mathrm{a}$ & $8.25 \mathrm{ab}$ & $4.05 \mathrm{a}$ & $12.31 \mathrm{a}$ \\
\hline & RY1015 & $11.06 \mathrm{a}$ & $3.09 \mathrm{a}$ & $14.15 \mathrm{~b}$ & $9.03 \mathrm{a}$ & $3.1 \mathrm{a}$ & $12.12 \mathrm{a}$ & $8.90 \mathrm{a}$ & $3.41 \mathrm{~b}$ & $12.31 \mathrm{a}$ & $8.70 \mathrm{a}$ & $3.27 \mathrm{~b}$ & $11.97 \mathrm{a}$ \\
\hline & Mean & $10.44 \mathrm{~B}$ & $3.19 \mathrm{~B}$ & $13.63 \mathrm{~B}$ & $8.22 \mathrm{~B}$ & $2.74 \mathrm{AB}$ & $10.96 \mathrm{~B}$ & $8.08 \mathrm{~B}$ & $3.39 \mathrm{~A}$ & $11.47 \mathrm{AB}$ & $7.88 \mathrm{~B}$ & $3.47 \mathrm{~A}$ & $11.35 \mathrm{~B}$ \\
\hline \multirow{5}{*}{ СTTP } & $\mathrm{HHZ}$ & $9.85 \mathrm{c}$ & $3.48 \mathrm{a}$ & $13.32 \mathrm{c}$ & $8.03 \mathrm{~b}$ & $2.04 \mathrm{c}$ & $10.07 \mathrm{~b}$ & $7.62 \mathrm{~b}$ & $2.99 \mathrm{c}$ & $10.62 \mathrm{~b}$ & $8.06 \mathrm{bc}$ & $3.30 \mathrm{~b}$ & $11.36 \mathrm{~b}$ \\
\hline & JNSM & $9.45 \mathrm{c}$ & $3.40 \mathrm{a}$ & $12.86 \mathrm{c}$ & $7.65 \mathrm{~b}$ & $2.16 \mathrm{c}$ & $9.80 \mathrm{~b}$ & $6.30 \mathrm{c}$ & $3.24 \mathrm{~b}$ & $9.54 \mathrm{c}$ & $7.77 \mathrm{c}$ & $3.30 \mathrm{~b}$ & $11.07 \mathrm{~b}$ \\
\hline & NY103 & $11.37 \mathrm{a}$ & $3.28 \mathrm{a}$ & $14.65 \mathrm{a}$ & $8.64 \mathrm{a}$ & $3.73 \mathrm{a}$ & $12.38 \mathrm{a}$ & $9.29 \mathrm{a}$ & $3.63 \mathrm{a}$ & $12.92 \mathrm{a}$ & $8.68 \mathrm{ab}$ & $4.21 \mathrm{a}$ & $12.89 \mathrm{a}$ \\
\hline & RY1015 & $10.74 \mathrm{~b}$ & $3.27 \mathrm{a}$ & $14.01 \mathrm{~b}$ & $9.15 \mathrm{a}$ & $2.77 \mathrm{~b}$ & $11.92 \mathrm{a}$ & $8.99 \mathrm{a}$ & $3.35 \mathrm{~b}$ & $12.33 \mathrm{a}$ & $9.25 \mathrm{a}$ & $3.42 \mathrm{~b}$ & $12.67 \mathrm{a}$ \\
\hline & Mean & $10.35 \mathrm{~B}$ & $3.36 \mathrm{AB}$ & $13.71 \mathrm{~B}$ & $8.37 \mathrm{~B}$ & $2.67 \mathrm{~B}$ & $11.04 \mathrm{~B}$ & $8.05 \mathrm{~B}$ & $3.30 \mathrm{~A}$ & $11.35 \mathrm{~B}$ & $8.44 \mathrm{~A}$ & $3.56 \mathrm{~A}$ & $12.00 \mathrm{~A}$ \\
\hline \multicolumn{14}{|c|}{ Analysis of variance } \\
\hline Treatment & & ** & ns & ** & $* *$ & * & $* *$ & ** & ns & ** & ** & ns & ** \\
\hline Cultivar & & ** & $\mathrm{ns}$ & ** & ** & ** & ** & ** & ** & ** & ** & $* *$ & ** \\
\hline $\mathrm{T} \times \mathrm{C}$ & & ns & $\mathrm{ns}$ & ns & ns & $* *$ & * & * & ns & * & ns & ns & ns \\
\hline
\end{tabular}

Table 3. Main season yield, ratoon season yield and annual yield of four rice cultivars grown under four

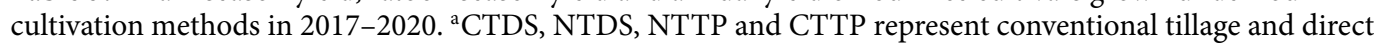
seeding, no-tillage and direct seeding, no-tillage and transplanting and conventional tillage and transplanting respectively. ${ }^{b} \mathrm{HHZ}$, JNSM, NY103 and RY015 are Huanghuazhan, Jinnongsimiao, Nei6you103 and Rongyou1015, respectively. Within a column means followed by the same letter are not significantly different according to LSD at $\mathrm{P}=0.05$. Lower-case and upper-case letters indicate comparison among four Cultivars and between four cultivation treatments, respectively. ${ }^{\star}$ Significant at $P<0.05,{ }^{* \star}$ Significant at $P<0.01$, ns, not significant at $P<0.05$.

main rice crop for the CTDS and NTDS treatments than for the CTTP treatment, respectively (Table 4). Consequently, the spikelets per $\mathrm{m}^{2}$ in the main rice crop for the CTDS and NTDS treatments were $14.0 \%$ and $12.4 \%$ higher than for the CTTP treatment, respectively. The number of panicles per $\mathrm{m}^{2}$ in the main rice crop for the NTTP treatment was 5.0\% lower than for the CTTP treatment; however, the number of spikelets per panicle for main rice crop was $3.4 \%$ higher for the NTTP treatment compared to CTTP. There was not significantly difference in spikelets per $\mathrm{m}^{2}$ between NTTP and CTTP treatment. The differences in grain filling and grain weight in the main rice crop among the four cultivation methods were relatively small.

The inbred cultivar 'Huanghuazhan' had the highest number of panicles per $\mathrm{m}^{2}$ and 'Jinnongsimiao' had the most spikelets per panicle in the main growing season (Table 4). On average, the rice hybrids had $5.2 \%$ fewer panicles per $\mathrm{m}^{2}, 17.4 \%$ fewer spikelets per panicle and $19.7 \%$ fewer spikelets per $\mathrm{m}^{2}$ than did the rice inbreds in the main growing season, while grain filling and grain weight were $1.7 \%$ and $39.0 \%$ higher, respectively, in the rice hybrids compared to the inbred cultivars.

The panicles per $\mathrm{m}^{2}$, spikelets per $\mathrm{m}^{2}$, and grain weight in the main rice crop were higher in 2017 than in 2018, 2019, and 2020 (Table 4). The number of spikelets per panicle in the main rice crop was slightly lower in 2017 than in 2018, 2019, and 2020. The grain filling in the main rice crop was $0.6 \%$ lower in 2017 than in 2018 but $2.0-2.7 \%$ higher than 2019 and 2020 .

The yield components of ratoon rice were significantly affected by year $(\mathrm{Y})$, cultivation method treatment (T) and cultivar (C), except effect of T for grain weight (Table 5). The interactive effects of $\mathrm{Y} \times \mathrm{T}$ and $\mathrm{Y} \times \mathrm{C}$ were significant for yield components in the ratoon rice crop except for the interactive effect of $\mathrm{Y} \times \mathrm{T}$ for spikelets per panicle and grain weight. The interactive effect of $\mathrm{T} \times \mathrm{C}$ was not significant for number of panicles per $\mathrm{m}^{2}$, spikelets per panicle, spikelets per $\mathrm{m}^{2}$ or grain filling in ratoon rice but was significant for grain weight in ratoon rice. The interactive effect of $\mathrm{Y} \times \mathrm{T} \times \mathrm{C}$ was not significant for the number spikelets per panicle, number spikelets per $\mathrm{m}^{2}$, grain filling, or grain weight in ratoon rice but was significant for the number of panicles per $\mathrm{m}^{2}$ in ratoon rice. 


\begin{tabular}{|c|c|c|c|c|c|}
\hline Variable & Panicles per $\mathrm{m}^{2}$ & Spikelets per panicle & $\times 10^{3}$ Spikelets per $\mathrm{m}^{2}$ & Grain filling (\%) & Grain weight (mg) \\
\hline \multicolumn{6}{|l|}{ Treatment $(\mathrm{T})^{\mathrm{a}}$} \\
\hline CTDS & $354.2 \mathrm{a}$ & $121.4 \mathrm{~d}$ & $42.3 \mathrm{a}$ & $90.3 \mathrm{~b}$ & $24.9 \mathrm{a}$ \\
\hline NTDS & $327.9 \mathrm{~b}$ & $130.2 \mathrm{c}$ & $41.7 \mathrm{a}$ & $91.3 \mathrm{a}$ & $24.9 \mathrm{a}$ \\
\hline NTTP & $230.7 \mathrm{~d}$ & $159.9 \mathrm{a}$ & $36.2 \mathrm{c}$ & $91.3 \mathrm{a}$ & $24.7 \mathrm{a}$ \\
\hline CTTP & $242.8 \mathrm{c}$ & $154.6 \mathrm{~b}$ & $37.1 \mathrm{c}$ & $91.5 \mathrm{a}$ & $24.8 \mathrm{a}$ \\
\hline \multicolumn{6}{|l|}{ Cultivar $(\mathrm{C})^{\mathrm{b}}$} \\
\hline HHZ & $330.3 \mathrm{a}$ & $133.4 \mathrm{~b}$ & $42.1 \mathrm{~b}$ & $92.0 \mathrm{~b}$ & $21.9 \mathrm{c}$ \\
\hline JNSM & $263.0 \mathrm{~d}$ & $176.7 \mathrm{a}$ & $45.2 \mathrm{a}$ & $88.6 \mathrm{~d}$ & $19.6 \mathrm{~d}$ \\
\hline N6Y103 & $287.1 \mathrm{~b}$ & $121.9 \mathrm{c}$ & $34.1 \mathrm{~d}$ & $93.2 \mathrm{a}$ & $29.6 \mathrm{a}$ \\
\hline RY1015 & $275.2 \mathrm{c}$ & $134.1 \mathrm{~b}$ & $36.0 \mathrm{c}$ & $90.6 \mathrm{c}$ & $28.1 \mathrm{~b}$ \\
\hline \multicolumn{6}{|l|}{ Year $(\mathrm{Y})$} \\
\hline 2017 & $331.4 \mathrm{a}$ & $138.1 \mathrm{~b}$ & $44.1 \mathrm{a}$ & $92.0 \mathrm{a}$ & $25.2 \mathrm{a}$ \\
\hline 2018 & $279.1 \mathrm{~b}$ & $140.3 \mathrm{~b}$ & $37.5 \mathrm{c}$ & $92.6 \mathrm{a}$ & $24.6 \mathrm{c}$ \\
\hline 2019 & $273.0 \mathrm{~b}$ & $138.1 \mathrm{~b}$ & $36.2 \mathrm{~d}$ & $89.6 \mathrm{~b}$ & $24.9 \mathrm{~b}$ \\
\hline 2020 & $272.1 \mathrm{~b}$ & $149.6 \mathrm{a}$ & $39.6 \mathrm{~b}$ & $90.2 \mathrm{~b}$ & $24.6 \mathrm{c}$ \\
\hline \multicolumn{6}{|c|}{ Analysis of variance } \\
\hline Year $(\mathrm{Y})$ & $* *$ & $* *$ & $* *$ & $* *$ & $* *$ \\
\hline Treatment (T) & $* *$ & $* *$ & $* *$ & * & ns \\
\hline Cultivar (C) & ** & ** & $* *$ & $* *$ & ** \\
\hline $\mathrm{Y} \times \mathrm{T}$ & $* *$ & $* *$ & $\mathrm{~ns}$ & ns & ns \\
\hline $\mathrm{Y} \times \mathrm{C}$ & $* *$ & $* *$ & $* *$ & $* *$ & $* *$ \\
\hline $\mathrm{T} \times \mathrm{C}$ & $* *$ & $* *$ & * & ns & ns \\
\hline $\mathrm{Y} \times \mathrm{T} \times \mathrm{C}$ & $* *$ & $* *$ & $* *$ & ns & ns \\
\hline
\end{tabular}

Table 4. Yield components of four rice cultivars grown under four cultivation methods in main crop season in 2017-2020. ${ }^{\mathrm{a}} \mathrm{CTDS}$, NTDS, NTTP and CTTP represent conventional tillage and direct seeding, no-tillage and direct seeding, no-tillage and transplanting and conventional tillage and transplanting respectively. ${ }^{b} \mathrm{HHZ}$, JNSM, NY103 and RY015 are Huanghuazhan, Jinnongsimiao, Nei6you103 and Rongyou1015, respectively. Means within each variable sharing the same letter are not significantly different according to LSD at $\mathrm{P}=0.05$. ${ }^{\star}$ Significant at $P<0.05,{ }^{*}$ Significant at $P<0.01$, ns, not significant at $P<0.05$.

The number of panicles per $\mathrm{m}^{2}$ in ratoon rice for the CTDS and NTDS treatments were $21.9 \%$ and $13.4 \%$ higher, respectively, than in the CTTP treatment, while there were $8.5 \%$ and $2.7 \%$ fewer spikelets per panicle, respectively, in ratoon rice in the CTDS and NTDS treatments compared to CTTP (Table 5). Consequently, the spikelets per $\mathrm{m}^{2}$ in ratoon rice for the CTDS and NTDS treatments were $8.2 \%$ and $9.9 \%$ higher, respectively, than in the CTTP treatment. Grain filling in ratoon rice in the CTDS and NTDS treatments was lower than in the CTTP treatment by $5.2 \%$ and $4.6 \%$, respectively. The differences in yield components of ratoon rice between the CTTP and NTTP treatments were relatively small, and there were no significant differences in grain weight among the four cultivation methods.

The hybrid 'Nei6you 107' had the highest number of panicles per $\mathrm{m}^{2}$ and the cultivar 'Jinnongsimiao' had the most spikelets per panicle in the ratoon season (Table 5). On average, rice hybrids had fewer panicles per $\mathrm{m}^{2}$, fewer spikelets per panicle, fewer spikelets per $\mathrm{m}^{2}$ and less grain filling than the inbred cultivars by $2.0 \%, 10.5 \%$, $12.4 \%$ and $9.0 \%$ in the ratoon season, respectively, while grain weight in the rice hybrids was $48.5 \%$ higher than in the inbred lines in the ratoon season.

The number of panicles per $\mathrm{m}^{2}$ and spikelets per $\mathrm{m}^{2}$ were the highest in 2017, and the number of spikelets per panicle was the highest in the 2020 in ratoon season (Table 5). Grain filling in ratoon rice in 2017 and 2018 was significantly lower than it was in 2019 and 2020. The differences in grain weight in ratoon rice among the four years were relatively small or inconsistent.

Biomass production and harvest index. Total dry matter and harvest index in the main season rice crop were significantly affected by year $(\mathrm{Y})$, cultivation method treatment $(\mathrm{T})$ and cultivar $(\mathrm{C})$ (Table 6). The interactive effects of $\mathrm{Y} \times \mathrm{T}, \mathrm{Y} \times \mathrm{C}, \mathrm{T} \times \mathrm{C}$, and $\mathrm{Y} \times \mathrm{T} \times \mathrm{C}$ were significant for total dry matter and harvest index in the main season rice crop. The total dry matter of the main rice crop in the CTDS and NTDS treatments was higher than in the CTTP treatment by $15.9 \%$ and $14.7 \%$, respectively, whereas the harvest indexes of the main rice crop in the CTDS and NTDS treatments were lower than in the CTTP treatment by $2.4 \%$ and $1.8 \%$, respectively. The NTTP treatment produced $4.5 \%$ less total dry matter in the main rice crop than the CTTP treatment; however, the harvest index of the main rice crop in the NTTP treatment was $1.7 \%$ higher than in the CTTP treatment. The rice hybrids had $12.6 \%$ higher total dry matter compared to the inbred cultivars in the main season. The difference in the harvest index for the main rice crop between the hybrids and the inbred cultivars was relatively small. The total dry matter was highest in 2017 and the harvest index was highest in 2020 in the main growing season. 


\begin{tabular}{|c|c|c|c|c|c|}
\hline Variable & Panicles per $\mathrm{m}^{2}$ & Spikelets per panicle & $\times 10^{3}$ Spikelets per $\mathrm{m}^{2}$ & Grain filling (\%) & Grain weight (mg) \\
\hline \multicolumn{6}{|l|}{ Treatment $(\mathrm{T})^{\mathrm{a}}$} \\
\hline CTDS & $352.2 \mathrm{a}$ & $55.8 \mathrm{~b}$ & $18.5 \mathrm{a}$ & $72.9 \mathrm{~b}$ & $21.1 \mathrm{a}$ \\
\hline NTDS & $327.3 \mathrm{~b}$ & $59.3 \mathrm{a}$ & $18.8 \mathrm{a}$ & $73.4 \mathrm{~b}$ & $21.3 \mathrm{a}$ \\
\hline NTTP & $279.4 \mathrm{c}$ & $61.4 \mathrm{a}$ & $16.8 \mathrm{~b}$ & $76.9 \mathrm{a}$ & $21.1 \mathrm{a}$ \\
\hline CTTP & $288.7 \mathrm{c}$ & $61.0 \mathrm{a}$ & $17.1 \mathrm{~b}$ & $76.9 \mathrm{a}$ & $21.1 \mathrm{a}$ \\
\hline \multicolumn{6}{|l|}{ Cultivar $(\mathrm{C})^{\mathrm{b}}$} \\
\hline HHZ & $338.7 \mathrm{a}$ & $58.0 \mathrm{~b}$ & $19.2 \mathrm{a}$ & $76.3 \mathrm{~b}$ & $17.5 \mathrm{c}$ \\
\hline JNSM & $291.5 \mathrm{~b}$ & $67.3 \mathrm{a}$ & $18.7 \mathrm{a}$ & $80.8 \mathrm{a}$ & $16.5 \mathrm{~d}$ \\
\hline N6Y103 & $342.5 \mathrm{a}$ & $51.4 \mathrm{c}$ & $17.1 \mathrm{~b}$ & $71.7 \mathrm{c}$ & $25.4 \mathrm{a}$ \\
\hline RY1015 & $274.9 \mathrm{~b}$ & $60.7 \mathrm{~b}$ & $16.1 \mathrm{~b}$ & $71.2 \mathrm{c}$ & $25.1 \mathrm{~b}$ \\
\hline \multicolumn{6}{|l|}{ Year $(\mathrm{Y})$} \\
\hline 2017 & $385.4 \mathrm{a}$ & $64.1 \mathrm{~b}$ & $24.4 \mathrm{a}$ & $72.0 \mathrm{~b}$ & $21.3 \mathrm{~b}$ \\
\hline 2018 & $322.0 \mathrm{~b}$ & $54.2 \mathrm{c}$ & $17.2 \mathrm{~b}$ & $71.4 \mathrm{~b}$ & $20.1 \mathrm{c}$ \\
\hline 2019 & $337.2 \mathrm{~b}$ & $45.6 \mathrm{~d}$ & $15.1 \mathrm{c}$ & $78.6 \mathrm{a}$ & $22.0 \mathrm{a}$ \\
\hline 2020 & $203.0 \mathrm{c}$ & $73.6 \mathrm{a}$ & $14.5 \mathrm{c}$ & $78.1 \mathrm{a}$ & $21.1 \mathrm{~b}$ \\
\hline \multicolumn{6}{|c|}{ Analysis of variance } \\
\hline Year $(\mathrm{Y})$ & $* *$ & $* *$ & $* *$ & $* *$ & $* *$ \\
\hline Treatment (T) & $* *$ & ** & ** & ** & ns \\
\hline Cultivar (C) & $* *$ & ** & ** & ** & ** \\
\hline $\mathrm{Y} \times \mathrm{T}$ & * & ns & * & ** & ns \\
\hline $\mathrm{Y} \times \mathrm{C}$ & $* *$ & ** & *** & ** & ** \\
\hline $\mathrm{T} \times \mathrm{C}$ & ns & ns & ns & ns & * \\
\hline $\mathrm{Y} \times \mathrm{T} \times \mathrm{C}$ & * & ns & ns & ns & ns \\
\hline
\end{tabular}

Table 5. Yield components of four rice cultivars grown under four cultivation methods in the ratoon rice season in 2017-2020. ${ }^{a}$ CTDS, NTDS, NTTP and CTTP represent conventional tillage and direct seeding, no-tillage and direct seeding, no-tillage and transplanting and conventional tillage and transplanting respectively. ${ }^{b} \mathrm{HHZ}$, JNSM, NY103 and RY015 are Huanghuazhan, Jinnongsimiao, Nei6you103 and Rongyou1015, respectively. Means within each variable sharing the same letter are not significantly different according to LSD at $\mathrm{P}=0.05$. ${ }^{\star}$ Significant at $P<0.05$, ${ }^{*}$ Significant at $P<0.01$, ns, not significant at $P<0.05$.

Total dry matter and harvest index in the ratoon rice were significantly affected by year $(\mathrm{Y})$, cultivation method treatment $(\mathrm{T})$ and cultivar $(\mathrm{C})$ (Table 6). The interactive effects of $\mathrm{Y} \times \mathrm{T}, \mathrm{Y} \times \mathrm{C}$, and $\mathrm{Y} \times \mathrm{T} \times \mathrm{C}$ were significant for total dry matter and harvest index in ratoon rice (Table 6). The interactive effect of $\mathrm{T} \times \mathrm{C}$ was not significant for biomass production or harvest index in ratoon rice. The total dry matter of ratoon rice in the CTDS and NTDS treatments was $8.5 \%$ and $9.6 \%$ higher, respectively, than in the CTTP treatment. The harvest index of ratoon rice in the CTDS and NTDS treatments were lower than in the CTTP treatment by $4.3 \%$ and $3.3 \%$, respectively. The total dry matter and harvest index of ratoon rice in the NTTP and CTTP treatments were the same. On average, the rice hybrids had $18.7 \%$ higher total dry matter than the rice inbreds in the ratoon season; however, the harvest index was $1.2 \%$ lower for the rice hybrids than for the inbreds in the ratoon season. The total dry matter and harvest index of ratoon rice were the highest in 2017.

\section{Discussion}

Our results show that there are significant differences in the main season yield, ratoon season yield, and annual yield among the four cultivation methods in the rice-ratoon rice cropping system (Table 3). Dong et al. found no differences in the main season yield, ratoon season yield, and annual yield between direct-seeded rice and transplanted rice in the rice-ratoon rice cropping system ${ }^{14}$. In contrast, Liu et al. reported that main season yield, ratoon season yield, and annual yield of direct-seeded and seedling broadcasting rice were significantly lower than the yields for manually transplanted seedlings ${ }^{28}$. In the present study, the main season yields in the CTDS and NTDS treatments were 2.8-6.1\% higher than in the CTTP treatment, while the ratoon season yields in the CTDS and NTDS treatments were similar to or higher than the yields in the CTTP treatment. Consequently, CTDS and NTDS produced 3.2-4.4\% higher annual yields than did CTTP. On average, a high annual yield of $>12 \mathrm{t} \mathrm{ha}^{-1}$ was achieved for CTDS and NTDS. The main season yields, ratoon season yields, and annual yields for rice grown in the NTTP and CTTP treatments were equal. These results suggest that CTTP can be replaced with CTDS and NTDS to maintain high rice grain yields and save on labor costs for rice production in the riceratoon rice cropping system.

The higher main season and ratoon season yields in the CTDS and NTDS treatments can be attributed to the higher sink size (spikelets per $\mathrm{m}^{2}$ ) and number of panicles per $\mathrm{m}^{2}$, which was significantly higher for CTDS and NTDS than for CTTP (Tables 4,5). The high contribution of panicle number to grain yield in rice production has also been reported by Huang et al. and Lin and $\mathrm{Luo}^{29,30}$. However, these studies only analyzed the contribution of yield components to grain yield in single-season rice. Therefore, it is difficult to understand whether the 


\begin{tabular}{|c|c|c|c|c|}
\hline \multirow[b]{2}{*}{ Variable } & \multicolumn{2}{|l|}{ Main season } & \multicolumn{2}{|l|}{ Ratoon season } \\
\hline & Total dry matter $\left(\mathrm{g} \mathrm{m}^{-2}\right)$ & Harvest index (\%) & Total dry matter $\left(\mathrm{g} \mathrm{m}^{-2}\right)$ & Harvest index (\%) \\
\hline \multicolumn{5}{|l|}{ Treatment $(\mathrm{T})^{\mathrm{a}}$} \\
\hline CTDS & $1767.0 \mathrm{a}$ & $52.9 \mathrm{c}$ & $654.6 \mathrm{a}$ & $42.8 \mathrm{c}$ \\
\hline NTDS & $1748.6 \mathrm{a}$ & $53.2 \mathrm{c}$ & $660.9 \mathrm{a}$ & $43.2 \mathrm{bc}$ \\
\hline NTTP & $1455.7 \mathrm{c}$ & $55.1 \mathrm{a}$ & $586.4 \mathrm{~b}$ & $44.4 \mathrm{ab}$ \\
\hline CTTP & $1524.5 \mathrm{~b}$ & $54.2 \mathrm{~b}$ & $603.1 \mathrm{~b}$ & $44.7 \mathrm{a}$ \\
\hline \multicolumn{5}{|l|}{ Cultivar $(\mathrm{c})^{\mathrm{b}}$} \\
\hline $\mathrm{HHZ}$ & $1581.2 \mathrm{c}$ & $54.0 \mathrm{a}$ & $600.4 \mathrm{~b}$ & $42.4 \mathrm{c}$ \\
\hline JNSM & $1474.1 \mathrm{~d}$ & $53.4 \mathrm{~b}$ & $544.9 \mathrm{c}$ & $45.7 \mathrm{a}$ \\
\hline N6Y103 & $1738.7 \mathrm{a}$ & $54.1 \mathrm{a}$ & $722.1 \mathrm{a}$ & $43.2 \mathrm{bc}$ \\
\hline RY1015 & $1701.8 \mathrm{~b}$ & $53.9 \mathrm{ab}$ & $637.6 \mathrm{~b}$ & $43.8 \mathrm{~b}$ \\
\hline \multicolumn{5}{|l|}{ Year $(\mathrm{Y})$} \\
\hline 2017 & $1884.0 \mathrm{a}$ & $53.4 \mathrm{~b}$ & $763.9 \mathrm{a}$ & $47.4 \mathrm{a}$ \\
\hline 2018 & $1581.1 \mathrm{~b}$ & $53.4 \mathrm{~b}$ & $576.4 \mathrm{c}$ & $42.6 \mathrm{c}$ \\
\hline 2019 & $1488.3 \mathrm{~d}$ & $53.1 \mathrm{~b}$ & $629.2 \mathrm{~b}$ & $41.0 \mathrm{~d}$ \\
\hline 2020 & $1542.4 \mathrm{c}$ & $55.6 \mathrm{a}$ & $535.6 \mathrm{~d}$ & $44.1 \mathrm{~b}$ \\
\hline \multicolumn{5}{|c|}{ Analysis of variance } \\
\hline Year $(\mathrm{Y})$ & $* *$ & $* *$ & $* *$ & $* *$ \\
\hline Treatment (T) & $* *$ & $* *$ & $* *$ & $* *$ \\
\hline Cultivar (C) & $* *$ & * & $* *$ & $* *$ \\
\hline $\mathrm{Y} \times \mathrm{T}$ & $* *$ & $* *$ & ** & $* *$ \\
\hline $\mathrm{Y} \times \mathrm{C}$ & $* *$ & $* *$ & $* *$ & $* *$ \\
\hline $\mathrm{T} \times \mathrm{C}$ & $* *$ & * & ns & ns \\
\hline $\mathrm{Y} \times \mathrm{T} \times \mathrm{C}$ & $* *$ & $* *$ & $* *$ & ** \\
\hline
\end{tabular}

Table 6. Biomass and harvest index of four rice cultivars grown four cultivation methods in main crop-

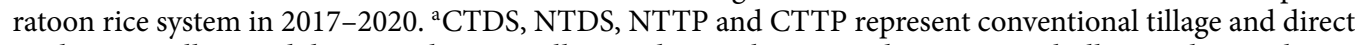
seeding, no-tillage and direct seeding, no-tillage and transplanting and conventional tillage and transplanting respectively. ${ }^{b} \mathrm{HHZ}$, JNSM, NY103 and RY015 are Huanghuazhan, Jinnongsimiao, Nei6you103 and Rongyou1015, respectively. Means within each variable sharing the same letter are not significantly different according to LSD at $\mathrm{P}=0.05$. ${ }^{\star}$ Significant at $P<0.05,{ }^{*}$ Significant at $P<0.01$, ns, not significant at $P<0.05$.

contributions of yield components to grain yield vary with the rice-growing season. In the present study, the panicle number per $\mathrm{m}^{2}$ in the main rice crop and in ratoon rice for CTDS and NTDS was significantly higher than for CTTP, while the number of spikelets per panicle in the main rice crop and ratoon rice for CTDS and NTDS was lower than for CTTP. The average number of panicles per $\mathrm{m}^{2}$ in ratoon rice for the CTDS and NTDS treatments were 13.4-21.9\% higher than in the CTTP treatment; which was associated with higher number of panicles per $\mathrm{m}^{2}$ in main rice crop for the CTDS and NTDS treatments compared with in the CTTP treatment. In other words, the adoption of direct-seeded rice can lead to higher number of panicles per $\mathrm{m}^{2}$ in main season and sufficient mother stems in ratoon season, resulting in high yields that resulted from higher in number of panicles per $\mathrm{m}^{2}$ in main crop-ratoon rice systems. The differences in grain filling and grain weight in the main rice crop and in ratoon rice among the four cultivation methods was relatively small or inconsistent. Therefore, improving panicle number per $\mathrm{m}^{2}$ is the key to increasing both main season and ratoon season yields in the rice-ratoon rice cropping system. The adoption of direct-seeded rice may also be a feasible approach towards achieving high number of panicles per $\mathrm{m}^{2}$ in the rice-ratoon rice cropping system.

In another approach, rice grain yield is determined by biomass production and harvest index ${ }^{31}$. However, it is generally thought that further improvements in rice grain yield might be driven by increasing the biomass production rather than the harvest index ${ }^{32,33}$, because there is little room to further increase the harvest index ${ }^{34}$. Consistently, in the present study, biomass production in the main rice crop and in ratoon rice in the CTDS and NTDS treatments was significantly higher than in the CTTP treatment; however, the harvest index of both the main and ratoon rice crops in the CTDS and NTDS treatments was significantly lower than in the CTTP treatment. This result indicates that further improvement in biomass production is important for improving rice grain yield while sustaining a high harvest index in the rice-ratoon rice cropping system. Biomass production can be increased by increasing dry weight per plant or plant number per unit land area, or both. In the present study, higher biomass production for both the main and ratoon rice crops in the CTDS and NTDS treatments compared to CTTP was mainly due to a higher plant number per unit land area, because the dry weight per plant of the main rice crop and ratoon rice in the CTDS and NTDS treatments was lower than in the CTTP treatment (data not shown). Our results indicate that direct-seeding is a feasible strategy to increase tiller numbers that results in high plant number per unit land area and high biomass production in the rice-ratoon rice cropping system.

The difference in main season, ratoon season, and annual rice yields between hybrid and inbred rice cultivars were significant in all four experiments. However, the magnitude of the differences in main season yield and 
ratoon season yield between the hybrid and inbred rice cultivars varied by crop establishment methods. The main season yield gap between hybrid and inbred rice cultivars was larger in transplanting treatment, but the ratoon season yield gap between the hybrid and inbred rice cultivars was larger in direct seeding treatment. The average main season and ratoon season yield of rice hybrids was significantly higher than that of rice inbreds, which was associated with longer growth duration, higher biomass and grain weight in rice hybrids compared with rice inbred (Table 3). The critical importance of biomass production to yield stability was previously emphasized by Jiang et al. and Zhang et al. ${ }^{32,33}$. The difference in main season yield between hybrid and inbred rice cultivars was mainly resulted from higher solar radiation during grain filling period (Table 2). However, the higher ratoon season yield in rice hybrids was associated with lower temperature during grain filling period compared with and rice inbred (Table 2). The number panicle per unit land area in ratoon rice mainly depended on the number of regenerated buds. Sprouting of axillary buds in ratoon rice requires certain conditions including temperature, light, humidity, and soil water content. Of all ecological conditions, the daily average temperature was the most important factor affecting regenerated buds growth; the duration of sunshine was second. The optimum temperature and relative humidity for sprouting axillary buds were $25-28{ }^{\circ} \mathrm{C}$ and the germination rate of axillary buds increased as the daily average temperature increased ${ }^{35,36}$. In the present study, the average panicles per $\mathrm{m}^{2}$ and spikelets per panicle in rice hybrids were lower than those in inbred lines in ratoon season. The difference in panicles per $\mathrm{m}^{2}$ and spikelets per panicle in ratoon season between hybrid and inbred rice cultivars were mainly resulted from the lower maximum and minimum temperatures and solar radiation in the ratoon crop growing season in rice hybrids, especially from harvest of the main rice crop to heading of the ratoon rice.

The average main season yield was 1.9-2.3 $\mathrm{t} \mathrm{ha}^{-1}$ higher in 2017 than that in 2018-2020, which was associated with higher biomass and larger sink size that resulted from more panicles per $\mathrm{m}^{2}$ in 2017 compared with 2018-2020. The high maximum and minimum temperatures and solar radiation during tillering period (30 days after transplanting) of main rice crop might have contributed to the high panicles per $\mathrm{m}^{2}$ in 2017 . More interesting, the sink size of main rice crop was larger in 2017 than in 2019 and 2020, though the grain filing was consistently higher in 2017 than 2019 and 2020 (Table 4). It is probable that lower solar radiation during grain filling period in 2019 and 2020 compared with 2017 reduced the grain filling of main rice crop ${ }^{37}$.

Rice hybrids not only had less variation in annual yield across four years, but also exhibited the smaller annual yield variability across management treatments compared with inbred lines. Annual yield in 2018, 2019 and 2020 was lower than in 2017 by $14.0-15.2 \%$ for rice hybrids and by $16.2-20.1 \%$ for inbred lines. Compared with CTTP, NTTP reduced annual yield by $2.0 \%$ and $1.0 \%$ for inbred lines and rice hybrids, respectively; CTDS and NTDS increased annual yield by $3.7-4.4 \%$ and $2.8-4.3 \%$ for inbred lines and rice hybrids, respectively. The simplified cultivation methods (NTTP, CTDS and NTDS) did not decrease or increase the annual yield of rice hybrids as much as in inbred lines. In other words, the rice hybrids was less sensitive to simplified cultivation methods than the inbred lines. Those results suggest that rice hybrids are more suitable than inbred cultivars to achieve high main season yields, ratoon season yields, and annual yields under simplified cultivation methods in southwest China. Similarly, previous studies have demonstrated that rice hybrids produce higher ratoon season yields and annual yields than do rice inbreds in direct seeded rice-ratoon rice cultivation systems ${ }^{14,38}$. The higher main season, ratoon season, and annual yields of rice hybrids compared to inbred cultivars can be attributed to the long growth duration and higher grain weight and biomass production, which suggests that developing cultivars with high grain weight and biomass production through breeding may also be a feasible approach to achieve high rice yield in the rice-ratoon rice cropping system in southwest China.

\section{Conclusion}

Main season yields, ratoon season yields, and annual yields in the CTDS and NTDS treatments were higher than those in the CTTP treatment in the rice-ratoon rice cropping system in southwest China. The higher rice grain yields of direct-seeded rice in the CTDS and NTDS treatments were associated with higher panicle number per $\mathrm{m}^{2}$ and biomass production. This result indicates that CTTP can be replaced with CTDS and NTDS to maintain high rice grain yields and to save labor costs for rice production in the rice-ratoon rice cropping system in southwest China. Rice hybrids produced higher main season yields, ratoon season yields, and annual yields than inbred cultivars. The high grain yields produced by rice hybrids were attributed to long growth duration, high grain weight and biomass production. This suggests that breeding and selecting rice cultivars with high grain weight and biomass production may also be a feasible approach towards achieving high grain yields in the rice-ratoon rice cropping system in southwest China.

\section{Methods}

A fixed field experiment was conducted in Fuji Town $\left(29^{\circ} 10^{\prime} \mathrm{N}, 105^{\circ} 23^{\prime} \mathrm{E}, 280 \mathrm{~m}\right.$ asl $)$ in Luxian County, Sichuan Province, China, from 2017 to 2020 . The location has a subtropical zone humid climate with a mean annual temperature of $17.8^{\circ} \mathrm{C}$, mean annual rainfall of $1065 \mathrm{~mm}$, mean annual relative humidity of $84 \%$, mean annual sunshine of $1390 \mathrm{~h}$, and an annual frost-free period of 341 days. The soil from the upper $20 \mathrm{~cm}$ surface layer contained $1.5 \mathrm{~g} \mathrm{~kg}^{-1}$ total nitrogen (N), $495.5 \mathrm{mg} \mathrm{kg}^{-1}$ total phosphorus, $31.6 \mathrm{~g} \mathrm{~kg}^{-1}$ total potassium, $30.3 \mathrm{~g} \mathrm{~kg}^{-1}$ organic matter, $150 \mathrm{mg} \mathrm{kg}^{-1} \mathrm{NaOH}$ hydrolysable $\mathrm{N}, 4.4 \mathrm{mg} \mathrm{kg}^{-1}$ Olsen P, $162.0 \mathrm{mg} \mathrm{kg}^{-1} \mathrm{NH}_{4} \mathrm{OAc}$-extractable K, and had a $\mathrm{pH}$ of 4.3 .

Four regionally popular and widely-adopted rice varieties, the hybrids 'Nei6you103' (NY103) and 'Rongyou1015' (RY1015) and the elite inbred cultivars 'Huanghuazhan' (HHZ) and 'Jinnongsimiao' (JNSM), were used in this experiment. Plant seeds were provided by the following organizations and persons: Rice and Sorghum Research Institute, Sichuan Academy of Agricultural Sciences and Rice Research Institute, Guangdong Academy of Agricultural Sciences. In each year, the hybrids NY103 and RY1015 and the elite inbreds HHZ and JNSM were grown using four cultivation methods: conventional tillage and transplanting (CTTP), conventional tillage 
and direct seeding (CTDS), no-tillage and transplanting (NTTP), and no-tillage and direct seeding (NTDS). Plots were arranged in a split-plot design with cultivation method as the main plot and rice cultivars as the subplots. Each treatment was replicated three times and the sub-plot size was $20 \mathrm{~m}^{2}$. The land preparation for the conventional tillage plots was carried out by plowing followed by a single harrowing, and for the no-tillage plots, herbicide was applied one week before planting. For transplanting, the seedlings were raised in a seedbed and 31 - to 35-day-old seedlings were transplanted at a spacing of $26.4 \mathrm{~cm} \times 20 \mathrm{~cm}$ with two seedlings per hill. For direct-seeding, pre-germinated seeds were broadcasted onto the soil surface at a seeding rate of $22.5 \mathrm{~kg} \mathrm{ha}^{-1}$ on March 15th in each year. The fertilizers used were urea for nitrogen $(\mathrm{N})$, single superphosphate for phosphorus $(\mathrm{P})$, and potassium chloride for potassium $(\mathrm{K})$ at doses of $225 \mathrm{~kg} \mathrm{~N} \mathrm{ha}^{-1}, 67.5 \mathrm{~kg} \mathrm{P}_{2} \mathrm{O}_{5} \mathrm{ha}^{-1}$, and $150 \mathrm{~kg} \mathrm{~K}_{2} \mathrm{O} \mathrm{ha}^{-1}$. $\mathrm{N}$ was applied in four splits: $40 \%$ as basal, $20 \%$ at mid-tillering, $20 \%$ at panicle initiation, and $20 \%$ at 10 days fullheading of the main rice crop. P was applied as basal. $\mathrm{K}$ was applied in three splits: $50 \%$ as basal, $30 \%$ at panicle initiation, and $20 \%$ at 10 days full-heading of the main rice crop. Water management practices were as follows: water was drained off completely before sowing, maintaining soil saturation from sowing to the three-leaf stage of the main rice crop, after which the fields were kept flooded for the entire growing season. Insects, diseases, and weeds were intensively controlled throughout the entire growing season to avoid yield loss.

At the maturity stages of the main and ratoon crops, plants were sampled from an area of $0.48 \mathrm{~m}^{2}$ in the directed-seeded subplots and six hills in the transplanted subplots to determine the yield components, aboveground total biomass, and harvest index. After counting the number of panicles, the plants were separated into straw and grains by manual threshing. Filled spikelets were separated from the unfilled spikelets by submerging them in tap water. Both the filled and unfilled spikelets were then air dried. Three subsamples $(30 \mathrm{~g}$ each) of the filled spikelets and all unfilled spikelets were counted to calculate the number of spikelets per panicle, the percentage of filled spikelets, and grain weight. After oven-drying to a constant weight at $70{ }^{\circ} \mathrm{C}$, the dry weights of the straw and the filled and unfilled spikelets were determined. Aboveground total biomass was calculated as the sum of the total dry matter of the straw and the filled and unfilled spikelets. The harvest index was calculated as the ratio of filled grain dry weight to aboveground total biomass. Grain yield was determined from a $5-\mathrm{m}^{2}$ area in the middle of each plot and adjusted to a moisture content of $14 \%$.

The Statistix 8 software package (Analytical Software, Tallahassee, Florida, USA) was used for analysis of variance (ANOVA). The statistical model for ANOVA included replication, treatment (T), cultivar (C), year (Y), the two-factor interactions of $\mathrm{T} \times \mathrm{C}, \mathrm{T} \times \mathrm{Y}$, and $\mathrm{C} \times \mathrm{Y}$, and the three-factor interaction of $\mathrm{T} \times \mathrm{C} \times \mathrm{Y}$. The statistical significance was set at the 0.05 probability level.

Ethical approval. The study complies with local and national regulations.

\section{Data availability}

All data generated or analysed during this study are included in the article.

Received: 21 June 2021; Accepted: 2 September 2021

Published online: 16 September 2021

\section{References}

1. Fageria, N. K. Yield physiology of rice. J. Plant Nutr. 30, 843-879 (2007).

2. Yamano, T., Arouna, A., Labarta, R. A., Huelgas, Z. M. \& Mohanty, S. Adoption and impacts of international rice research technologies. Global Food Sec. 8, 1-8 (2016).

3. Peng, S. B., Tang, Q. Y. \& Zou, Y. B. Current status and challenges of rice production in China. Plant Prod. Sci. 12, 3-8 (2009).

4. Cassman, K. G., Dobermann, A., Walters, D. T. \& Yang, H. Meeting cereal demand while protecting natural resources and improving environmental quality. Annu. Rev. Environ. Resour. 28, 315-358 (2003).

5. Ray, D. K. \& Foley, J. A. Increasing global crop harvest frequency: Recent trends and future directions. Environ. Res. Lett. 8, 044041. https://doi.org/10.1088/1748-9326/8/4/044041 (2013).

6. Long, H. L. Land consolidation: An indispensable way of spatial restructuring in rural China. J. Geogr. Sci. 24, 211-225 (2014).

7. Licker, R. et al. Mind the gap: How do climate and agricultural management explain the yield gap of croplands around the world. Glob. Ecol. Biogeogr. 19, 769-782 (2010).

8. Mishra, A., Whitten, M., Ketelaar, J. W. \& Salokhe, V. M. The System of Rice Intensification (SRI): A challenge for science, and an opportunity for farmer empowerment towards sustainable agriculture. Int. J. Agric. Sust. 8, 193-212 (2011).

9. Fan, M. S., Lu, S. H., Jiang, R. F., Liu, X. J. \& Zhang, F. S. Triangular transplanting pattern and split nitrogen fertilizer application increase rice yield and nitrogen fertilizer recovery. Agron. J. 101, 1421-1425 (2009).

10. Yang, J., Huang, D., Duan, H., Tan, G. \& Zhang, J. Alternate wetting and moderate soil drying increases grain yield and reduces cadmium accumulation in rice grains. J. Sci. Food Agric. 89, 1728-1736 (2010).

11. Xu, L. et al. Yield performance of direct-seeded, double-season rice using varieties with short growth durations in central China. Field Crop Res. 227, 49-55 (2018).

12. Chen, Q. et al. Comparisons of regeneration rate and yields performance between inbred and hybrid rice cultivars in a direct seeding rice-ratoon rice system in central China. Field Crop Res. 223, 164-170 (2018).

13. Xu, F. X. et al. Progress in research of yield formation of ratooning rice and its high-yielding key regulation technologies. Sci. Agric. Sin. 48, 1702-1717 (2015).

14. Dong, H. L. et al. The growth and yield of a wet-seeded rice-ratoon rice system in central China. Field Crops Res. 208, 55-59 (2017).

15. Wang, Y. C. et al. Agronomic responses of ratoon rice to nitrogen management in central China. Field Crop Res. 241, 107569 (2019).

16. Lin, Q., Wang, Y. H., Lin, Q., Zhou, F. M. \& Zhang, J. F. Yield formation and key screening indicators ratooning rice under simplified cultivation. J. Northwest Agric. Forest. Univ. (Nat. Sci. Ed.) 48, 38-47 (2020).

17. Ziska, L. H., Fleisher, D. H. \& Linscombe, S. Ratooning as an adaptive management tool for climatic change in rice systems along a north-south transect in the southern Mississippi valley. Agric. Forest Meteorol. 263, 409-416 (2018).

18. Adigbo, S. O., Olojede, M. O., Harris, P. J. C. \& Ajayi, O. Ratooned lowland Nerica rice varieties as an option for triple cropping in inland valleys of derived Savannah in Nigeria. Exp. Agric. 48, 551-562 (2012).

19. Itabiyi, O. V. I., Adebowale, A. A., Shittu, T. A., Adigbo, S. O. \& Sanni, L. O. Effect of ratooning process on the engineering properties of Nerica rice varieties. Qual. Assur. Saf. Crop. 8, 21-31 (2016). 
20. Wang, Y. C., Li, X. F., Lee, T., Peng, S. B. \& Dou, F. G. Effects of nitrogen management on the ratoon crop yield and head rice yield in South USA. J. Integr. Agr. 20, 1457-1464 (2021).

21. Thomas, E. V. Development of a mechanism for transplanting rice seedlings. Mech. Mach. Theory 37, 395-410 (2002).

22. Kumar, V. \& Ladha, J. K. Direct seeding of rice: Recent developments and future research needs. Adv. Agron 111, 297-413 (2011).

23. Jiang, Q. W. et al. Response of first flood irrigation timing after rice dry-direct-seeding: Productivity and greenhouse gas emissions in Central China. Agric. Water Manag. 177, 241-247 (2016)

24. Tao, Y., Chen, Q., Peng, S. B., Wang, W. Q. \& Nie, L. X. Lower global warming potential and higher yield of wet direct-seeded rice in Central China. Agron. Sustain. Dev. 36, 1-9 (2016).

25. Lin, Q. et al. Relationship of panicle to stem ratio with yield and its components of ratoon rice. J. Northwest Agric. Forest. Univ. (Nat. Sci. Ed.) 49, 1-11 (2021).

26. Wang, H. et al. Advances in the effects of the ability of axillary bud germination on grain yield in ratoon rice. Chin. J. Rice Sci. 34, 205-2016 (2020).

27. Huang, M. et al. No-tillage and direct seeding for super hybrid rice production in rice-oilseed rape cropping system. Eur. J. Agron. 34, 278-286 (2011).

28. Liu, K. L., Qin, J. T. \& Zhang, B. Effects on source-sink of ratoon rice under simplified cultivation of different seeding stages. Soils 44, 686-695 (2012).

29. Huang, M. et al. Relationship between grain yield and yield components in super Hybrid rice. Agric. Sci. China 10, 1537-1544 (2010).

30. Lin, Q. \& Luo, W. L. The analysis of the yield component of super hybrid rice II Youhang 2 and approaches of its yield increase. Chin. Agric. Sci. Bull. 23, 244-246 (2007).

31. Yang, W., Peng, S., Laza, R. C., Visperas, R. M. \& Dionisio-Sese, M. L. Yield gap analysis between dry and wet season rice crop grown under high-yielding management conditions. Agron. J. 100, 1390-1395 (2008).

32. Jiang, P. et al. Potential yield increase of hybrid rice at five locations in Southern China. Rice https://doi.org/10.1186/s12284-0160085-6 (2016).

33. Zhang, Y. B. et al. Yield potential and radiation use efficiency of super hybrid rice grown under subtropical conditions. Field Crop Res. 114, 91-98 (2009).

34. Evans, L. T. \& Fischer, R. A. Yield potential: Its definition, measurement and significance. Crop Sci. 39, 1544-1551 (1999).

35. Xiong, H. \& Fang, W. Ecological study on germination and yield formation of alfalfa buds in ratoon rice. Acta Ecol. Sin. 2, 161-167 (1994).

36. Yang, Z. M., Liu, H. L. \& Wang, L. Effects of light and temperature on yield of ratooning rice. J. Chin. J. Ecol. Agric. 15, 87-90 (2007).

37. Wang, D. P. et al. Temperature explains the yield difference of doubleseason rice between tropical and subtropical environments. Field Crop Res. 198, 303-311 (2016).

38. Chen, Q. et al. Comparison of regeneration rate and yields performance between inbred and hybrid rice cultivars in a direct seeding rice-ratoon rice system in central China. Filed Crop Res. 223, 164-170 (2018).

\section{Acknowledgements}

Financial support was provided by the National Natural Science Foundation of China (31971844), the earmarked fund for China Agriculture Research System (CARS-01-25), and the foundation of excellent paper program of Sichuan Agricultural Sciences Academy (2017LWJJ-009).

\section{Author contributions}

P.J. and F.X. conceived the study. P.J., L.Z., H.X., X.G., Y.Z. and X.Z. performed the experiment and collected the data. P.J. analysed the data and wrote the manuscript. All authors reviewed the manuscript.

\section{Competing interests}

The authors declare no competing interests.

\section{Additional information}

Correspondence and requests for materials should be addressed to P.J. or F.X.

Reprints and permissions information is available at www.nature.com/reprints.

Publisher's note Springer Nature remains neutral with regard to jurisdictional claims in published maps and institutional affiliations.

(c) (1) Open Access This article is licensed under a Creative Commons Attribution 4.0 International cc) License, which permits use, sharing, adaptation, distribution and reproduction in any medium or format, as long as you give appropriate credit to the original author(s) and the source, provide a link to the Creative Commons licence, and indicate if changes were made. The images or other third party material in this article are included in the article's Creative Commons licence, unless indicated otherwise in a credit line to the material. If material is not included in the article's Creative Commons licence and your intended use is not permitted by statutory regulation or exceeds the permitted use, you will need to obtain permission directly from the copyright holder. To view a copy of this licence, visit http://creativecommons.org/licenses/by/4.0/.

(c) The Author(s) 2021 